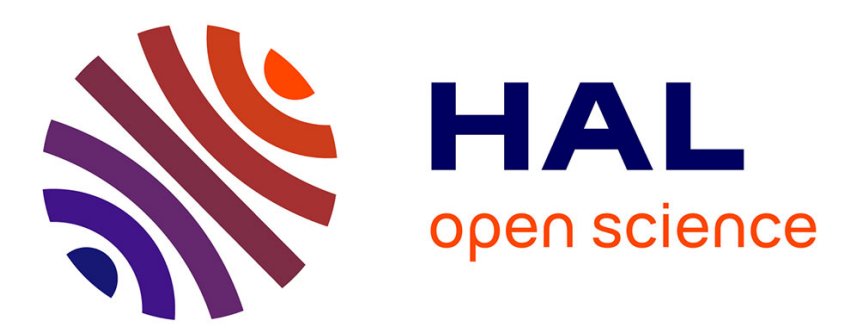

\title{
Rheological properties of pomegranate peel suspensions: The effect of fibrous material and low-methoxyl pectin at acidic $\mathrm{pH}$
}

Mouna Abid, S. Cheikhrouhou, Gerard G. Cuvelier, Cassandre Leverrier, Catherine M.G.C. Renard, Hamadi Attia, Med Ali Ayadi

\section{To cite this version:}

Mouna Abid, S. Cheikhrouhou, Gerard G. Cuvelier, Cassandre Leverrier, Catherine M.G.C. Renard, et al.. Rheological properties of pomegranate peel suspensions: The effect of fibrous material and low-methoxyl pectin at acidic pH. Food Hydrocolloids, 2017, 62, pp.174-181. 10.1016/j.foodhyd.2016.08.008 . hal-02622170

\section{HAL Id: hal-02622170 \\ https: / hal.inrae.fr/hal-02622170}

Submitted on 26 May 2020

HAL is a multi-disciplinary open access archive for the deposit and dissemination of scientific research documents, whether they are published or not. The documents may come from teaching and research institutions in France or abroad, or from public or private research centers.
L'archive ouverte pluridisciplinaire HAL, est destinée au dépôt et à la diffusion de documents scientifiques de niveau recherche, publiés ou non, émanant des établissements d'enseignement et de recherche français ou étrangers, des laboratoires publics ou privés. 


\title{
Rheological properties of pomegranate peel suspensions: The effect of fibrous material and low-methoxyl pectin at acidic $\mathrm{pH}$
}

\author{
Mouna Abid ${ }^{\mathrm{a}}$, S. Cheikhrouhou ${ }^{\mathrm{a}}$, Gérard Cuvelier ${ }^{\mathrm{b}}$, Cassandre Leverrier ${ }^{\mathrm{b}}$, \\ Catherine M.G.C. Renard ${ }^{\text {c, d }}$, Hamadi Attia a, M.A. Ayadi a, * \\ a Laboratoire Analyse, Valorisation et Sécurité des Aliments, Université de Sfax, Ecole Nationale d'Ingénieurs de Sfax (ENIS), BP 3038, Sfax, Tunisia \\ ${ }^{\mathrm{b}}$ UMR Ingénierie Procédés Aliments, AgroParisTech, INRA, Université Paris-Saclay, F-91300, Massy, France \\ ' INRA, UMR408 Sécurité et Qualité des Produits d'Origine Végétale, F-84000, Avignon, France \\ d Avignon Université, UMR408 Sécurité et Qualité des Produits d'Origine Végétale, F-84000, Avignon, France
}

Keywords:

Punica granatum L.

Rheology

Pectin

Fibrous material

Particle size

Gelation

\begin{abstract}
A B S T R A C T
The gel formation behaviour of four tunisian pomegranate peel powders was investigated at pH 3 in the presence of $30 \%$ sucrose and $1 \mathrm{~g} / \mathrm{L} \mathrm{CaCl}_{2}$. All gels show a rapid formation with $\mathrm{G}^{\prime}>\mathrm{G}^{\prime \prime}$, which reveals a typically gel-like structure. Since the mechanical properties of pomegranate peel gels are governed mainly by soluble pectins and/or insoluble fibrous material, the rheological properties of pectin and fibrous material gels were individually investigated. Results show that all systems displayed a typical solid-like behaviour, however the profiles obtained for the fibrous material gels (35 g/L fibrous material) were quantitatively higher than those obtained for pectins ( $7 \mathrm{~g} / \mathrm{L}$ pectin). Thus, the properties of the peel gels seem then to be mostly governed by fibrous material. However, the $G^{\prime}$ and $G^{\prime \prime}$ moduli obtained for fibrous material and pectin gels were significantly lower than those of peel suspensions. The rheological properties of peel gels would thus result from a strong synergism between fibrous material and pectins. The mechanical treatment was found to have a significant effect on fibrous material gel strength improvement which could be related to a lower sedimentation of suspensions. The particle size distributions revealed a decrease of fibrous material's particle size, and so an increase in surface area and a decrease of suspension's sedimentation. By heating samples at $82{ }^{\circ} \mathrm{C}$ for $1 \mathrm{~h}$, trimodal distributions were obtained for peel samples.
\end{abstract}

\section{Introduction}

Pomegranate (Punica granatum L.) is a fruit that belonging to the Punicacea family and it is considered to be a functional product of great benefit in the human diet (Mditshwa, Fawole, Al-Said, AlYahyai, \& Opara, 2013). The pomegranate fruits are normally consumed fresh or as fresh pomegranate juice, however, the pomegranate processing industry deals with the large percentage of byproducts such as peels.

Pomegranate peel which constitues up to $40 \%$ of the whole fruit, could have industrial applications and be used as ingredient in functional foods particularly as gelling agent due to its richness in pectin (the soluble pectic fraction) and fibrous material (the whole fibre complex including insoluble material). Gelation

\footnotetext{
* Corresponding author.

E-mail addresses: ayadimedali@yahoo.fr, ayadimedali@gmail.com (M.A. Ayadi).
}

of pectins is greatly affected by both extrinsic and intrinsic parameters including the degree of methylation (DM). Indeed, the mechanism of gel formation is different in both high-methoxyl (HM) and low-methoxyl (LM) pectins. HM pectins ( $\mathrm{DM}>50 \%$ ) form gels if the $\mathrm{pH}$ is below 3.6 and a cosolute is present, typically sucrose at a concentration greater than $55 \%$ by weight (Thakur, Singh, \& Handa, 1997). For low-methoxyl pectins $(\mathrm{DM}<50 \%)$, gelation is due to the chelation of calcium ions in regular arrays of electronegative cavities formed by the galacturonic acid residues. It requires so the presence of a controlled amount of calcium or other divalent cations. The gel formation occurs over a wide range of $\mathrm{pH}$ values, and the efficient $\mathrm{Ca}^{2+}$ binding is an important factor both at low and high $\mathrm{pH}$ values (Cardoso, Coimbra, \& Lopes da Silva, 2003). Pereira et al. (2016) reported that the degree of methylation of the extracted pectins from pomegranate peel, using citric acid, varied from $47 \%$ to $71 \%$, so mostly high methoxyl pectins were extracted. On the other hand, Srivastava and Malviya (2011) reported that the 
Version définitive du manuscrit publiée dans / Final version of the manuscript published in :

Food Hydrocolloids (2017), Vol. 215, p. 174-181, DOI: 10.1016/j.foodhyd.2016.08.008

Journal homepage : www.elsevier.com/locatelfoodhyd

composition of pectins (including the DM) varies with the source and the conditions applied during isolation.

Concerning the fibrous material, this fraction can provide a multitude of functional properties when it is incorporated in food systems. Thus, fibrous material addition contributes to the modification and improvement of the texture, sensory characteristics and shelf-life of foods due to their waterbinding capacity, gelforming ability, texturising and thickening effects (Dikeman, Murphy, \& Fahey, 2006; Gelroth \& Ranhotra, 2001; Kunzek, Muller, Vetter, \& Godeck, 2002). As fibrous plant cell walls play in important role in determining the food's quality that they go into, and as pectins and/or fibrous material would be the principal components governing the mechanical properties of the cell walls, knowing informations related to the rheology of these three components is highly important.

This study focuses on better understanding the rheological properties of pomegranate peel powder dispersions in water (from four varieties) in order to understand more precisely the effect of using pomegranate peel as gelling agent. The rheological behaviour of peel dispersion prepared from each variety was compared to that of pectin and fibrous material extracted from the same variety at acidic $\mathrm{pH}(\mathrm{pH} 3)$.

\section{Materials and methods}

\subsection{Plant material}

Mature pomegranate fruits, ecotypes “Acide” (Ac), “Gabsi” (Ga), "Nebli" (Ne) and "Tounsi" (To), were collected from the same oasis at Gabes region (southeast of Tunisia). Fruits were manually peeled then the collected peels were cut into small pieces. Samples were dried at $50{ }^{\circ} \mathrm{C}$, ground and milled through 0.5 and $1.25 \mathrm{~mm}$ sieves. Final powders with sizes between 0.5 and $1.25 \mathrm{~mm}$ and particles size $<0.5 \mathrm{~mm}$ were retained for pectin extraction and for gelation, respectively.

\subsection{Pectin extraction}

$2 \mathrm{~g}$ of pomegranate peel was stirred at $400 \mathrm{rpm}$ (Stirrer Heidolph RZR 20051 electronic, Germany) in $100 \mathrm{ml}$ of the $\mathrm{HNO}_{3}$ solution (solid-liquid ratio; $1: 50 ; \mathrm{g} / \mathrm{mL}$ ). The extraction conditions were $80 \mathrm{~min}, 86^{\circ} \mathrm{C}$ and $20 \mathrm{mmol} / \mathrm{L}$ nitric acid. The resulting slurries were allowed to cool to room temperature $\left(25{ }^{\circ} \mathrm{C}\right)$ and filtered through cheesecloth. Then, two volumes of $96 \% \mathrm{w} /$ $\mathrm{w}$ ethanol were added to the filtrate for pectin precipitation and the obtained mixture was kept for $1 \mathrm{~h}$ at $4{ }^{\circ} \mathrm{C}$. After centrifugation at $8000 \mathrm{~g}$ for $20 \mathrm{~min}$ at $10{ }^{\circ} \mathrm{C}$, the pectin precipitate was washed with 50\%, 75\% and two times with $100 \%$ ethanol and centrifuged at $5000 \mathrm{~g}$ for $10 \mathrm{~min}$ at $10{ }^{\circ} \mathrm{C}$. Finally, the obtained pectin was dried at $45{ }^{\circ} \mathrm{C}$ to a constant weight, ground in a mortar and stored at room temperature for further gels' preparation.

\subsection{Fibrous material extraction}

The fibrous material was extracted from fresh pomegranate peel previously maintained in hot water $\left(85^{\circ} \mathrm{C}\right)$ at the ratio of $4: 1(\mathrm{v} / \mathrm{w})$ for $5 \mathrm{~min}$. The mixture was then filtrated with a thin cloth in order to separate the insoluble residue. The concentration of the fibrous material was realised by a succession of two rinsings (water at $40^{\circ} \mathrm{C}-10 \mathrm{~min}$ ) until the residue was exempted from simple sugars. The fibrous material extracts were dried at $50{ }^{\circ} \mathrm{C}$ to a constant weight then milled. Final powders with sizes $<0.5 \mathrm{~mm}$ were retained for gelation.

\subsection{Peel gel preparation}

$637.5 \mathrm{~g}$ demineralized water, $7.5 \mathrm{ml} 54.3 \% \mathrm{w} / \mathrm{v}$ citric acid solution and sodium citrate solution $(6 \% \mathrm{w} / \mathrm{v})$ were mixed in a steel pot and $100 \mathrm{~g}$ peel powder, corresponding to 6.5-7.9 g dry pectin; 28-34 g total fibre (Table 1 ), was added. The suspension was heated at $82{ }^{\circ} \mathrm{C}$ while stirring for $1 \mathrm{~h}$. Then about $40 \mathrm{~g}$ saccharose was added while stirring. The suspension was heated quickly until boiling, $224 \mathrm{~g}$ saccharose was added in 3 portions and the solution was boiled again. Afterwards, calcium chloride solution was added, giving calcium concentration of $0.16 \mathrm{~g} / \mathrm{g}$ pectin, and while further boiling and stirring the total mass was reduced to $900 \mathrm{~g}$ (with final amounts: $0.72-0.88 \%$ pectin and $3.1-3.8 \%$ total fibre). The whole process should take no more than about $5 \mathrm{~min}$.

\subsection{Fibrous material gel preparation}

In order to compare the rheological behaviour of peel and fibrous material gels, only the fibrous material suspension of To ecotype (To1) was prepared at the same conditions used previously for the gelation of peel dispersions (including heating at $82^{\circ} \mathrm{C}-1 \mathrm{~h}$ ) (section 2.4) with $3.5 \%$ of fibrous material $(\mathrm{w} / \mathrm{w}$ ) (since the final amount of fibre in peel gels corresponds to $3.1-3.8 \%$ ). The dry solids content was reported to be as one of the parameters affecting gel strength (Imeson, 2010).

To get an indication of the effect of the dispersion mode, fibrous material suspensions of To ecotype were set for mechanical agitation with an Ultra Turrax at $20000 \mathrm{rpm}$ for 3 and $6 \mathrm{~min}$. Then, the suspensions were heated quickly until $90^{\circ} \mathrm{C}$, saccharose was added and the solution was boiled again. Afterwards, calcium chloride solution was added. To3 and To6 are the fibrous material gels corresponding to 3 and $6 \mathrm{~min}$ of mechanical agitation, respectively.

In order to compare the fibrous material dispersions' rheological behaviour of the different ecotypes, fibrous material extracted from Ac, Ga, Ne and To were subjected to gelation after mechanical agitation using an Ultra Turrax at $20000 \mathrm{rpm}$ for $3 \mathrm{~min}$.

\subsection{Pectin gel preparation}

For gel preparation at $\mathrm{pH} 3$, distilled water, citric acid solution $(54.3 \% \mathrm{w} / \mathrm{v})$ and sodium citrate solution $(6 \% \mathrm{w} / \mathrm{v})(\mathrm{pH} 3)$ were mixed with dry pectin powder and stirred for $120 \mathrm{~min}$ at $20{ }^{\circ} \mathrm{C}$ at $\mathrm{pH} 3$, in order to get a complete hydration. The mixtures were then heated, saccharose was added in 3 portions to a final concentration of $30 \%$ and the solution was heated more until boiling. Afterwards, calcium chloride ( $1 \mathrm{~g} / \mathrm{L}$ ) was added and mixed under intense agitation. The solution was boiled again. The final pectin concentration was $7 \mathrm{~g} / \mathrm{L}$.

\subsection{Rheological measurements}

The applied rheometer was a Physica MCR 301 (Anton Paar, Germany). Oscillation measurements (temperature sweep) of storage modulus $G^{\prime}$ and loss modulus $G^{\prime \prime}$, in the linear viscoelastic domain, were made using a coaxial cylinders wide gap CC18 for

Table 1

Sugar, fibre and pectin content in four selected pomegranate peels.

\begin{tabular}{lllll}
\hline$(\mathrm{mg} / \mathrm{g}, \mathrm{DW})$ & $\mathrm{Ac}$ & $\mathrm{Ga}$ & $\mathrm{Ne}$ & To \\
\hline Total sugar & $306.5 \pm 7.0^{\mathrm{a}}$ & $335.8 \pm 2.1^{\mathrm{ab}}$ & $330.0 \pm 29.9^{\mathrm{ab}}$ & $348.3 \pm 7.9^{\mathrm{b}}$ \\
Total fibre & $282.7 \pm 9.0^{\mathrm{a}}$ & $281.0 \pm 12.0^{\mathrm{a}}$ & $338.1 \pm 4.2^{\mathrm{b}}$ & $339.3 \pm 6.6^{\mathrm{b}}$ \\
Pectin & $66.3 \pm 4.0^{\mathrm{a}}$ & $78.6 \pm 8.1^{\mathrm{b}}$ & $75.9 \pm 3.4^{\mathrm{b}}$ & $64.5 \pm 2.3^{\mathrm{a}}$ \\
\hline
\end{tabular}

Ac, Acide; Ga, Gabsi; Ne, Nebli; To, Tounsi; DW, dry weight basis. Each value in the table is represented as mean $\pm S E(n=3)$. Significant differences between values in the same row are indicated by different letters $(P<0.05)$. 
peel and fibrous material gels and a double gap DG26.7 for pectin gels. Samples were transferred into the pre-heated rheometer $\left(90{ }^{\circ} \mathrm{C}\right.$ ) and cooled to $10{ }^{\circ} \mathrm{C}$ with a cooling rate of $2{ }^{\circ} \mathrm{C} / \mathrm{min}$. The samples were coated with silicone oil and the cylinder was closed with a special lid in order to avoid evaporation. Dynamic rheological parameter (G' and G") were recorded during cooling at a frequency of $1 \mathrm{~Hz}$ and deformation amplitude of $\gamma 0.1 \%$.

Oscillatory measurements were also conducted using the frequency sweep method in the range of $10-0.01 \mathrm{~Hz}$ at $10^{\circ} \mathrm{C}$ to study variations of $G^{\prime}$ and $G^{\prime \prime}$ as a function of frequency.

\subsection{Particle size distribution}

The particle size distribution (PSD) was measured using a laser diffraction analyser (Master Sizer, Malvern Instruments Ltd UK), applying the Fraunhofer optical model. The $d(0.9)$ represents the diameter above which there is only $10 \%$ (in volume) of bigger particles. Analysis was done on both dry and diluted powders of peel and fibrous material in the solution mentioned above (section 2.4) (demineralized water, citric acid solution and sodium citrate solution) at $\mathrm{pH} 3$. The PSD of the diluted suspensions (before $\left(\mathrm{S}_{0}\right)$ and after heating $\left(\mathrm{S}_{\mathrm{F}}\right)$ at $82^{\circ} \mathrm{C}-1 \mathrm{~h}$ and of fibrous material suspensions after mechanical treatment for $3 \mathrm{~min}\left(\mathrm{~S}_{3}\right)$ and $6 \mathrm{~min}\left(\mathrm{~S}_{6}\right)$ were measured after $24 \mathrm{~h}$ of hydration.

\subsection{Light microscopy}

Light microscopy was used to visualize the microstructure of the fibrous material gels using an Olympus BX51 microscope $(100 \times$, Olympus BX51 microscope, Olympus America, Lake Success, NY) equipped with a digital camera Basler A102FC (Basler AG, Ahrensburg, Germany).

\section{Results and discussion}

\subsection{Rheological characterization of gels}

\subsubsection{Pomegranate peel gelation}

The gel formation behaviour of pomegranate peel was investigated in the presence of $30 \%$ sucrose at $\mathrm{pH} 3$ and $1 \mathrm{~g} / \mathrm{L} \mathrm{CaCl}_{2}$. Fig. 1 shows the semi-logarithmic plots of $\mathrm{G}^{\prime}$ and $\mathrm{G}^{\prime \prime}$ versus time obtained from small amplitude oscillatory measurements (in the linear domain) at constant frequency $(1 \mathrm{~Hz})$ during controlled cooling. All gels show a rapid formation with $G^{\prime}>G^{\prime \prime}$ from the beginning of the

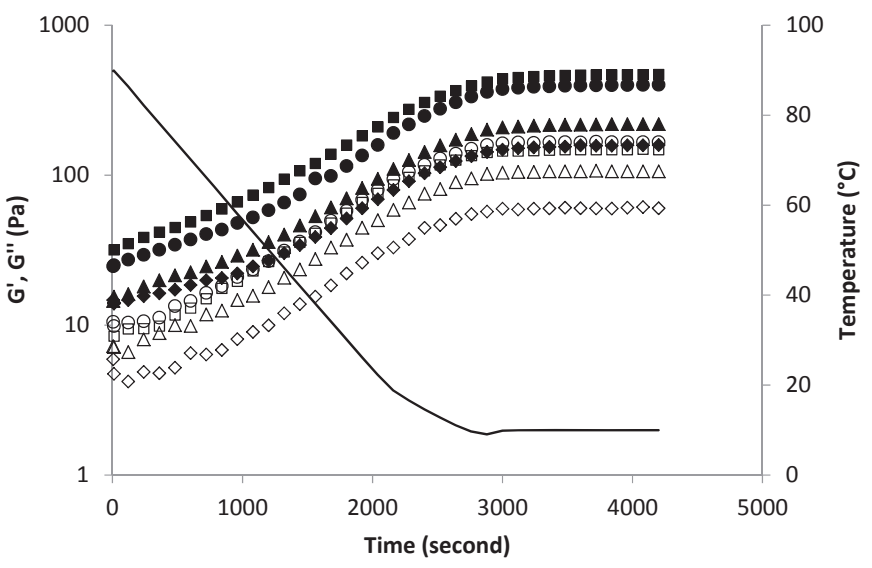

Fig. 1. Semi-logarithmic plots of $G^{\prime}$ and $G^{\prime \prime}$ vs time obtained at constant frequency $(1 \mathrm{~Hz})$ during controlled cooling $\left(2{ }^{\circ} \mathrm{C} / \mathrm{min}\right)$ of peel gels. $\mathrm{G}^{\prime} \mathrm{Ac}$ : $(\diamond), \mathrm{G}^{\prime \prime} \mathrm{Ac}$ : $(\diamond), \mathrm{G}^{\prime} \mathrm{Ga}$ : $(\boldsymbol{\Delta}), G^{\prime \prime}$ Ga: $(\Delta), G^{\prime}$ Ne: $(\bullet), G^{\prime \prime}$ Ne: $(\bigcirc), G^{\prime}$ To: $(\boldsymbol{\square}), G^{\prime \prime}$ To: $(\square)$, Temperature: (-). measurement at high temperatures, which reveals a typically gellike structure as a result of the contribution of pectin and particle interactions. During cooling from $90{ }^{\circ} \mathrm{C}$ to $10{ }^{\circ} \mathrm{C}$, the formed network was reinforced, which reflects the important role of temperature in gel reinforcement contrary to that of time. Indeed, at constant temperature $\left(10{ }^{\circ} \mathrm{C}\right) \mathrm{G}$ ' remained nearly stable over time.

For all samples $\mathrm{G}^{\prime}$ increased with decreasing temperature during cooling from $90{ }^{\circ} \mathrm{C}$ to $10^{\circ} \mathrm{C}$, however the Ne and To gels exhibited significantly higher storage modulus than those of the Ac and Ga gels at the same peel's concentration with lower $\operatorname{tg} \delta\left(G^{\prime \prime} / G^{\prime}\right)$, reflecting stronger and more structured gels. As a matter of fact, $\mathrm{Ne}$ and To gels showed about two times higher $G^{\prime}$ end (at the end of cooling at $\left.10^{\circ} \mathrm{C}\right)(401$ and $470 \mathrm{~Pa}$, repectively) compared to Ac and Ga gels (159 and $219 \mathrm{~Pa}$, respectively). The $\mathrm{G}^{\prime}$ increases almost 15 times under cooling for $\mathrm{Ne}$ and To ecotypes.

Since cellulose microfibrils and pectins are the principal components of primary cell wall where they play a significant role in the structuration (Agoda-Tandjawa, Durand, Gaillard, Garnier, \& Doublier, 2012a), we can suppose that the mechanical properties of pomegranate peel gels are governed mainly by pectins and/or fibrous material. In addition, the presence of calcium and/or sodium ions and the biopolymer concentrations were reported to have an influence on the properties of the mixed systems (cellulose/pectins). In presence of both sodium and calcium ions, the viscoelastic properties of the mixtures are rather governed by LM pectin (Agoda-Tandjawa, Durand, Gaillard, Garnier, \& Doublier, 2012b). Concerning the fibres' contribution, it was shown by Agoda-Tandjawa et al. (2010) that when cellulose fibres are properly dispersed in water by shearing forces, the obtained cellulosic microfibrils interact with each other to build a strong network that provides a gel-like structure to the aqueous medium, even at low concentration.

For pectins, it has been shown that pectins can play a determining role in structuring the plant cell walls trough the formation of calcium pectate gel in vivo controlled by the action of pectin methylesterase enzyme (PME) and their ihnibitors PMEI (Vincken et al., 2003). LM pectins are well-known to form gels in the presence of calcium ions over a wide range of $\mathrm{pH}$ (Axelos \& Thibault, 1991). Pectin gelation is affected also by temperature. Gel strength increases as temperature is lowered. At high temperature, short junction zones are formed, then upon cooling, these junction zones are stabilized through hydrogen bonding which is accompanied by cooperative calcium immobilisation (Fraeye, Duvetter, Doungla, Loey, \& Hendrickx, 2010).

Agoda-Tandjawa et al. (2012a) reported that the rigidity of cellulose/pectins composite was significantly influenced by the structural characteristics of pectins. Indeed, it appears that the pomegranate peel gel's strength is influenced by pectin's characteristics. In order to determine the relationship between chemical properties of pectins (in the presence of fibrous material) and rheological characteristics of peel gels, a multiple regression analysis was performed. For that, regression equations (data not shown)

Table 2

Galacturonic acid (GalA), elution times (ET), degree of methylation (DM) and total neutral sugar (TNS) of pectins extracted from pomegranate peels.

\begin{tabular}{lllll}
\hline Pectin & GalA $(\mathrm{mg} / \mathrm{g})$ & ET $(\mathrm{min})$ & DM & TNS $(\mathrm{mg} / \mathrm{g})$ \\
\hline Ac & $477.1 \pm 35.0^{\mathrm{c}}$ & 15.07 & $34.1 \pm 1.9^{\mathrm{b}}$ & $295.2 \pm 3.3^{\mathrm{a}}$ \\
$\mathrm{Ga}$ & $470.5 \pm 16.6^{\mathrm{c}}$ & 14.46 & $46.1 \pm 1.4^{\mathrm{a}}$ & $222.0 \pm 11.5^{\mathrm{b}}$ \\
$\mathrm{Ne}$ & $613.2 \pm 31.2^{\mathrm{b}}$ & 14.43 & $41.1 \pm 8.0^{\mathrm{a}}$ & $121.8 \pm 1.0^{\mathrm{c}}$ \\
To & $685.1 \pm 26.4^{\mathrm{a}}$ & 14.43 & $37.0 \pm 3.3^{\mathrm{ab}}$ & $123.1 \pm 0.9^{\mathrm{c}}$ \\
\hline
\end{tabular}

Ac, Acide; Ga, Gabsi; Ne, Nebli; To, Tounsi. Significant differences between values in the same column are indicated by different letters $(P<0.05)$. 
were determined for each variable (such as GalA, DM and neutral sugar content) (Table 2 ), using $\mathrm{G}^{\prime}$ end and $\tan \delta_{\text {end }}$ of the four varieties (Table 3). Results show that the higher the GalA, the higher the storage modulus ( $G^{\prime}$ end $)$ of pomegranate peel gels. The same effect was reported by Rinaudo (1996) who demonstrates that the elastic modulus at a constant weight concentration of pectin is directly proportional to the galacturonic acid yield.

For neutral sugars, it is clear that in presence of a higher amount, the storage modulus $\mathrm{G}^{\prime}$ was lower (Tables 2 and 3). This behaviour was related to the presence of side branches which could affect gelling properties (Hwang \& Kokini, 1992). This can be explained by the fact that neutral side chains in the pectin molecule hinder gel formation by preventing pectins' aggregation. (Smidsrod \& Haug, 1971).

It was found that with decreasing the degree of methylation (DM), gels prepared at a constant total pectin concentration had decreased values of $\tan \delta\left(G^{\prime \prime} / G^{\prime}\right)$ (Tables 2 and 3). These findings were consistent with those of Kim, Rao, and Smit (1978) who reported that the gel strength increases with decreasing DM in LM pectin.

This could be explained by the fact that the presence of methyl groups prevents the formation of junction zones in the interjunction segments of molecules, making them more flexible (Thakur et al., 1997). In addition, the molecules with an increased number of charged groups and lower degree of methoxylation are straighter than esterified ones, and hence more likely to form a $\mathrm{Ca}^{2+}$ bridge (Speiser, Copley, \& Nutting, 1947). The size of the aggregate that forms the junction zone depends on how much calcium is available (Thakur et al., 1997).

Therefore, peel gel's properties seemed to be influenced by fibrous material and/or pectin. The hydration of fibrous material might result in less volume available for pectin and therefore an increase of local pectin concentration. Moreover, in the presence of fibrous material, an increase in gel's strength is influenced by pectin's characteristics. It could have resulted from either decreasing DM, decreasing neutral sugar content or increasing GalA content.

Properties of peel gels prepared at the same conditions were also studied by frequency sweep (Fig. 2). Since the four peel gels showed similar type of profil of $G^{\prime}$ and $G^{\prime \prime}$ variations as a function of frequency, the profil presented in Fig. 2 was selected as a representative example in order to illustrate the type of profil of $G^{\prime}$ and $\mathrm{G}^{\prime \prime}$ variations for the studied preparations. The log-log representation of the elastic $\left(G^{\prime}\right)$ and the dynamic modulus $\left(G^{\prime \prime}\right)$ as a function of frequency shows a slight frequency dependence of moduli $G^{\prime}$ and $G^{\prime \prime}$ with an increase of $G^{\prime}$ and $G^{\prime \prime}$ when the frequency increases, indicating a gel-like behaviour with G'>G". At low values of frequency, a rubbery plateau was reached where G' remained nearly constant with decreasing frequency.

\subsubsection{Pectin gels}

Variations of elastic modulus $\left(\mathrm{G}^{\prime}\right)$ and viscous modulus $\left(\mathrm{G}^{\prime \prime}\right)$ as a function of time are shown in Fig. 3 for $\mathrm{LM}$ pectins extracted at $\mathrm{pH} 3$ from pomegranate peel (Ac, Ga, Ne and To), in the presence of $7 \mathrm{~g} / \mathrm{L}$

\section{Table 3}

Values of $G^{\prime}$ initial $\left(G_{0}^{\prime}\right), G^{\prime}$ at end of test $\left(G^{\prime}\right.$ end $)$ and $\tan \delta$ at end of test ( $\tan \delta$ end $)$ of pomegranate peel gels.

\begin{tabular}{llll}
\hline Ecotype & $\mathrm{G}_{0}^{\prime}(\mathrm{Pa})$ & $\mathrm{G}_{\text {end }}^{\prime}(\mathrm{Pa})$ & Tan $\delta$ end $\left(\mathrm{G}^{\prime \prime} / \mathrm{G}^{\prime}\right)$ \\
\hline $\mathrm{Ac}$ & 14.7 & 159 & 0.37 \\
$\mathrm{Ga}$ & 14.5 & 219 & 0.47 \\
$\mathrm{Ne}$ & 24.7 & 401 & 0.4 \\
$\mathrm{To}$ & 31.7 & 470 & 0.31 \\
\hline
\end{tabular}

Ac, Acide; Ga, Gabsi; Ne, Nebli; To, Tounsi.

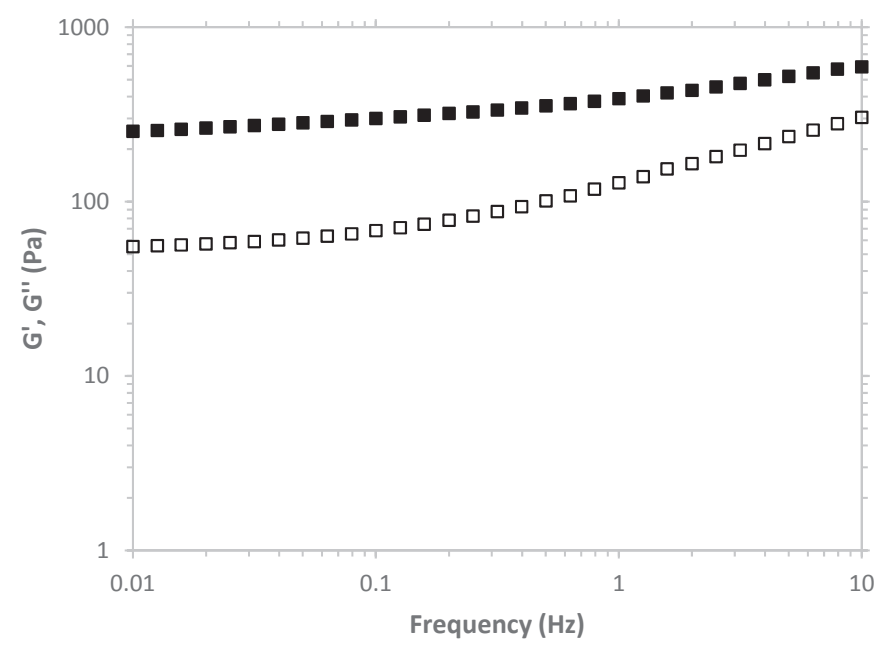

Fig. 2. Frequency sweep of pomegranate peel gel. G': (口), G”: ( $\square$ ).

pectin and $1 \mathrm{~g} / \mathrm{L} \mathrm{CaCl}_{2}$. This figure revealed the formation of a crosslinked network, which was characterized by the temperature dependence of $\mathrm{G}^{\prime}$ and $\mathrm{G}^{\prime \prime}$ on cooling. During cooling from $90{ }^{\circ} \mathrm{C}$ to $10^{\circ} \mathrm{C}$, the storage modulus $\left(\mathrm{G}^{\prime}\right)$ was greater to the loss modulus $\left(\mathrm{G}^{\prime \prime}\right)$ indicating a typically gel-like structure. $G^{\prime}$ increased continuously when temperature decreased from $90{ }^{\circ} \mathrm{C}$ to $10^{\circ} \mathrm{C}$. As shown in Fig. 3, the four samples reached the plateau at $10{ }^{\circ} \mathrm{C}$, displaying different $G_{\text {end }}$. To pectin exhibit a significantly higher storage modulus than those of other varieties at the same pectin concentration with greater separation of $\mathrm{G}^{\prime}$ and G". Thus, the gel To was characterized by a denser network with more interconnected chains. The variation in the pectin gel formation could be attributed to difference in pomegranate peel pectin characteristics such as the molecular weight and the neutral sugar content.

\subsubsection{Fibrous material gels}

The fibrous material suspension of To ecotype (To1) was prepared at the same conditions used previously for the gelation of peel dispersions in order to compare the rheological behaviour of peel and fibrous material gels. Tounsi ecotype was selected since the peel gel prepared from this ecotype exhibited the highest storage modulus with lower $\operatorname{tg} \delta\left(G^{\prime \prime} / G^{\prime}\right)$ compared to others varieties, which reflect stronger and more structured gels.

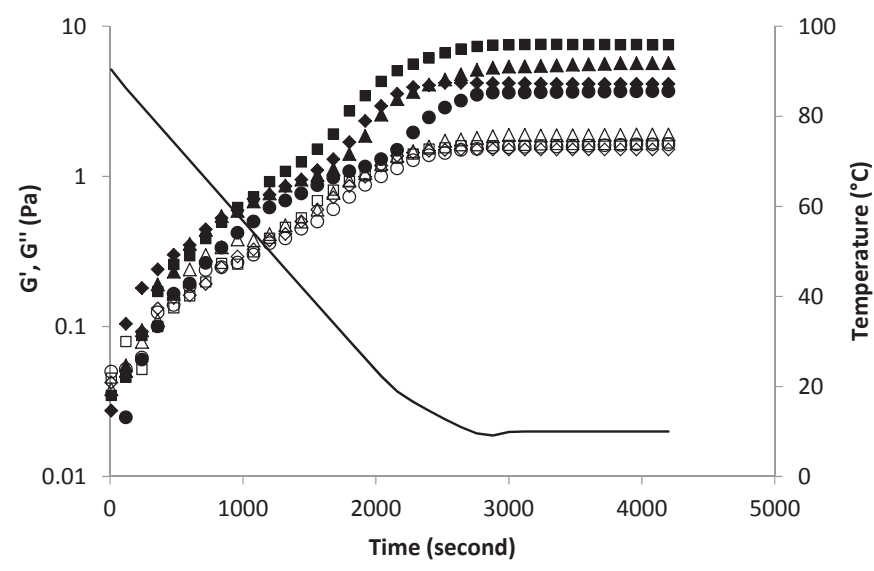

Fig. 3. Semi-logarithmic plots of $G^{\prime}$ and $G^{\prime \prime}$ vs time obtained at constant frequency $(1 \mathrm{~Hz})$ during controlled cooling $\left(2^{\circ} \mathrm{C} / \mathrm{min}\right)$ of pectin gels $\mathrm{G}^{\prime} \mathrm{Ac}$ : $(\diamond), \mathrm{G}^{\prime \prime} \mathrm{Ac}$ : $(\diamond), \mathrm{G}^{\prime} \mathrm{Ga}$ :

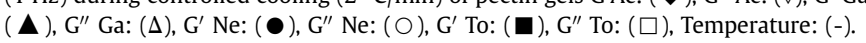



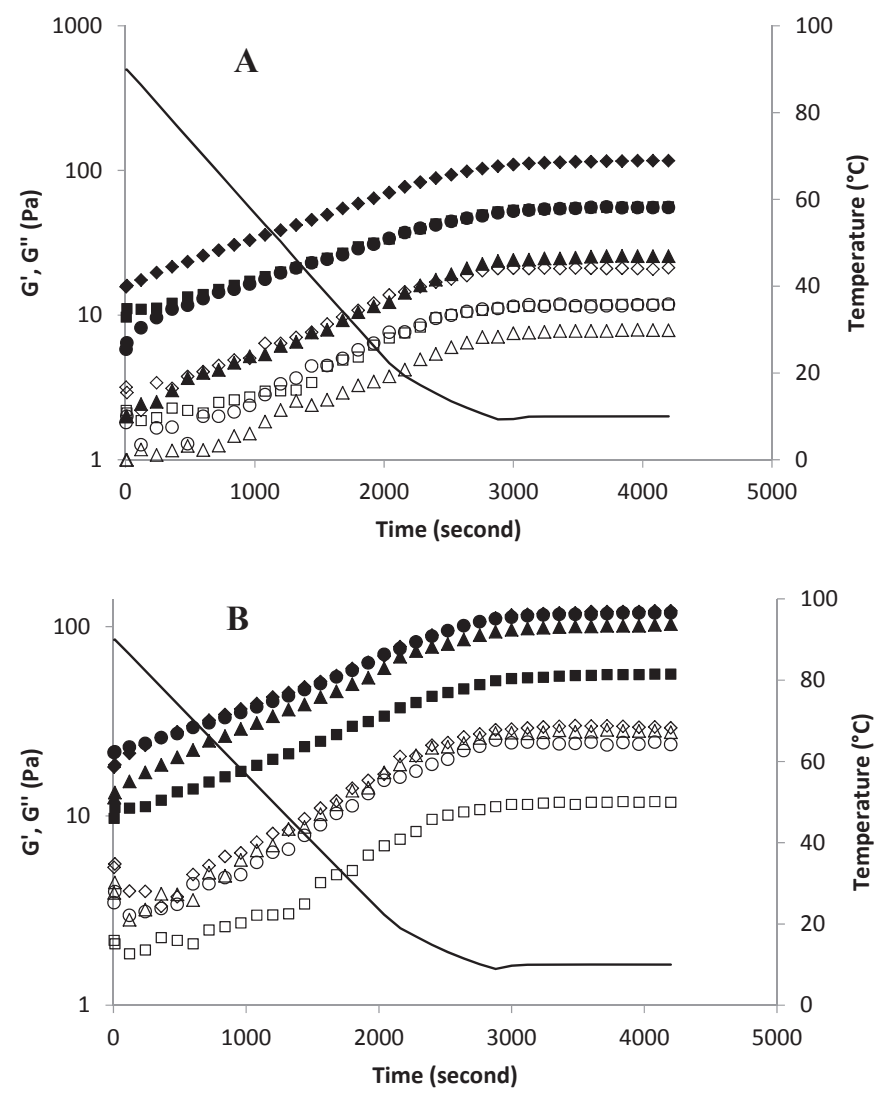

Fig. 4. Semi-logarithmic plots of $\mathrm{G}^{\prime}$ and $\mathrm{G}^{\prime \prime}$ vs time obtained at constant frequency $(1 \mathrm{~Hz})$ during controlled cooling $\left(2^{\circ} \mathrm{C} / \mathrm{min}\right)$ of fibrous material gels. (A) Effect of the grinding time (To1, To3 and To6) and that of calcium (To3 and To3') on Tounsi fibrous

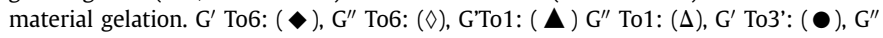
To3': (O), G' To3: ( $), G^{\prime \prime}$ To3: ( $\square$ ), Temperature: (-); (B) Rheological behaviour of fibrous material dispersions prepared from the four ecotypes after mechanical agitation (3 min) G'Ac: $(\bullet), G^{\prime \prime}$ Ac: $(\diamond), G^{\prime}$ Ga: $(\boldsymbol{\Delta}), G^{\prime \prime}$ Ga: $(\Delta), G^{\prime}$ Ne: $(\bullet), G^{\prime \prime}$ Ne: $(O), G^{\prime}$ To: (ם), G" To: ( $\square)$, Temperature: (-).

Fig. 4A shows the mechanical spectra obtained for To fibrous material gel (To1) in the presence of $30 \%$ sucrose, $1 \mathrm{~g} / \mathrm{L} \mathrm{CaCl} 2$ and $35 \mathrm{~g} / \mathrm{L}$ fibrous material. The variation of $\mathrm{G}^{\prime}$ and $\mathrm{G}^{\prime \prime}$, plotted as a function of time, indicated a gel-like behaviour with $G^{\prime}>G^{\prime \prime}$. In addition, it is clearly seen that the profile obtained for the fibrous material gel To1 was quantitatively higher than that obtained for pectin To (Figs. 3 and 4A). The properties of the peel gel To seemed then to be mostly governed by fibrous material, which can be considered as dispersed in a continuous aqueous phase containing pectins. However, the $G^{\prime}$ and $G^{\prime \prime}$ moduli obtained for fibrous material gel were much lower than those of peel suspension (Figs. 1 and $4 \mathrm{~A}$ ). This could be related to the alterability of some fibrous material functionalities during the extraction process. Dhingra, Michael, Rajput, and Patil (2012) reported that processes, such as grinding, drying, heating or extrusion cooking for example, modifies the physical properties of the fibre matrix and also affect the hydration properties. From these results, it appears that a strong synergism was noted for the peel gels between fibrous material and pectins. Zykwinska, Ralet, Garnier, and Thibault (2005) highlighted that sugar beet (Beta vulgaris) and potato (Solanum tuberosum) pectins rich in side chains can bind in vitro to cellulose microfibrils by adsorption. Furthermore, part of pectic backbones (and not side chains) were found strongly associated with cellulose. For the richness of side branches, pomegranate peel pectins are considered rich in neutral sugars in comparison with those of sugar beet pulp pectin (Buchholt, Christensen, Fallesen, Ralet, \& Thibault, 2004 (288 mg/g); Thibault, Renard, Axelos, Roger, \& Crépeau, 1993 (186 $\mathrm{mg} / \mathrm{g})$ ), which is already known for its high neutral sugar content relative to apple or citrus pectins (Voragen, Pilnik, Thibault, Axelos, \& Renard, 1995).

3.1.3.1. Effect of mechanical energy on fibrous material gelation. The role of the energy applied during dispersion on the viscoelastic properties of fibrous material is demonstrated by comparing fibrous material suspensions with mechanical grinding at $20000 \mathrm{rpm}$ for $3 \mathrm{~min}$ and $6 \mathrm{~min}$ (To3 and To6, respectively) to untreated one (To1). Variations of $G^{\prime}$ and $G^{\prime \prime}$ as a function of time are shown in Fig. 4A. It is clear that G' values of To1, To3 and To6 samples increased proportionally to the applied force duration. As a matter of fact, the storage modulus of To1, To3 and To6 increased slowly and remained constant after $3600 \mathrm{~s}$, plateauing to $\sim 30,60$ and $120 \mathrm{~Pa}$, respectively, meaning that the mechanical treatment had a significant effect on gel strength improvement. These observations show that, under grinding, fibrous material is more dispersed and then is able to form well-structured gels. Guillon and Champ (2000) reported that the physico-chemical properties of dietary fibre can be manipulated through treatments: chemical, enzymatic, mechanical, thermal or thermo mechanical to improve their functionality. Therefore, mechanical energy can also have profound effects on polysaccharides molecular weight distribution (Poutanen, Suirti, Aura, Luikkonen, \& Autio, 1998). Combination of thermal and mechanical energy can change dramatically the structure of dietary fibre at all structural level leading possibly to new functional properties.

Lowys, Desbrie Áres, and Rinaudo (2001) demonstrated that a more efficient dispersion mode had a positive effect on $G^{\prime}$ and $G^{\prime \prime}$ which could be related to a lower sedimentation of suspensions. A

Table 4

Peak particle size of dry and diluted peel and fibrous material powders.

\begin{tabular}{|c|c|c|c|c|c|c|c|c|}
\hline \multirow[t]{3}{*}{ Source } & \multirow[t]{3}{*}{ Ecotype } & \multicolumn{7}{|c|}{ Peak particle size $(\mu \mathrm{m})$} \\
\hline & & \multirow[t]{2}{*}{ Dry } & \multirow[t]{2}{*}{$\mathbf{S}_{0}$} & \multicolumn{3}{|l|}{$\mathbf{S}_{\mathrm{F}}$} & \multirow[t]{2}{*}{$\mathbf{S}_{3}$} & \multirow[t]{2}{*}{$\mathbf{S}_{6}$} \\
\hline & & & & Mode1 & Mode2 & Mode3 & & \\
\hline \multirow[t]{4}{*}{ Peel } & Ac & $316-363$ & 478 & 138 & 275 & 363 & & \\
\hline & $\mathrm{Ga}$ & & 416 & 138 & 239 & 363 & & \\
\hline & $\mathrm{Ne}$ & & 478 & 104 & 208 & 478 & & \\
\hline & To & & 478 & 138 & 208 & 363 & & \\
\hline \multirow[t]{4}{*}{ Fibrous material } & Ac & $316-363$ & 549 & & & & 275 & \\
\hline & $\mathrm{Ga}$ & & 549 & & & & 316 & \\
\hline & $\mathrm{Ne}$ & & 478 & & & & $275-316$ & \\
\hline & To & & 549 & & & 478 & $275-316$ & 239 \\
\hline
\end{tabular}

Ac, Acide; Ga, Gabsi; Ne, Nebli; To, Tounsi; $\mathrm{S}_{0}$, diluted suspensions before heating; $\mathrm{S}_{\mathrm{F}}$, diluted suspensions after heating at $82^{\circ} \mathrm{C}-1 \mathrm{~h} ; \mathrm{S}_{3}-\mathrm{S}_{6}$, fibrous material suspensions after mechanical agitation for 3 and $6 \mathrm{~min}$. 

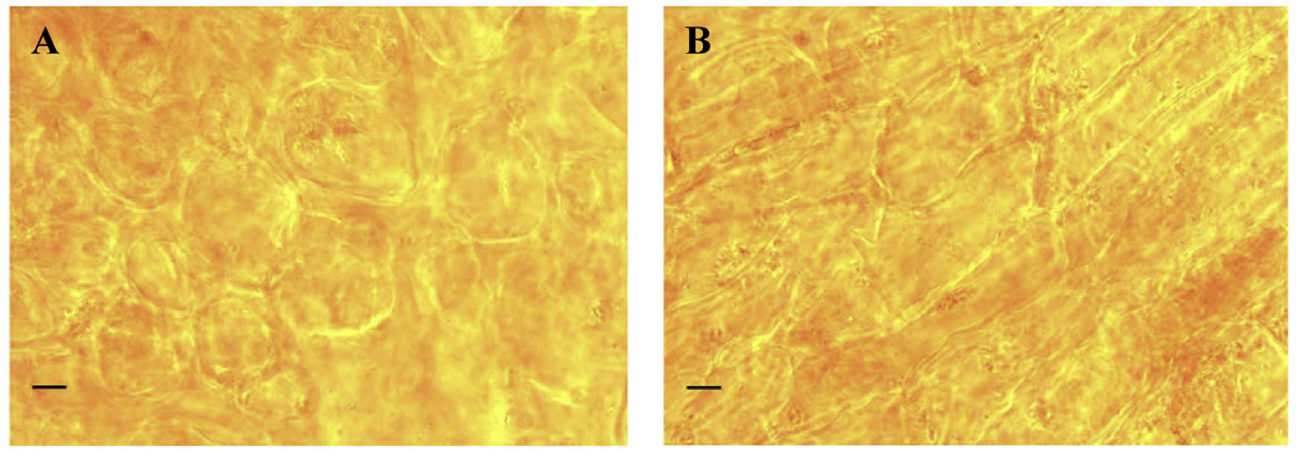

Fig. 5. Micrographs of fibrous material gels (from Tounsi ecotype) in the presence of $3.5 \%$ of fibrous material. (A) To1: untreated sample; (B) To6: set for mechanical treatment (6 min). $(-10 \mu \mathrm{m})$.

low sedimentation volume was related to a more regular fibre disperse systems by reducing the friction at the fibre contact points and so, it makes the fibres lie in the better order (Tatsumi, Kourogi, Chen, \& Matsumoto, 2008). These findings were consistent with the decrease of fibrous material's particle size in To sample, and so a decrease of suspension's sedimentation. Indeed, under mechanical treament until $3 \mathrm{~min}$, the peak particle size decreased from 549 to $275 \mu \mathrm{m}$ (Table 4). Raghavendra et al. (2006) evaluated the grinding characteristics of coconut residue and observed that the reduction in the particle size (from 1127 to $550 \mu \mathrm{m}$ ) resulted in increased hydration properties, which may be due to increase in surface area and total pore volume as well as structural modification. In contrast the storage $\left(\mathrm{G}^{\prime}\right)$ and loss $\left(\mathrm{G}^{\prime \prime}\right)$ moduli of To6 sample increased over those of To3 (Fig. 4A and Table 4), although the peak particle size decreased slightly during the mechanical agitation between 3 and $6 \mathrm{~min}$. Hence the increase of both moduli is related probably to the heat induced by mechanical treatment noticed after 3 min.

The study of the rheological behaviour of fibrous material dispersions prepared from the four ecotypes (Ac, Ga, Ne and To) after mechanical agitation ( $3 \mathrm{~min}$ ), showed that all systems displayed a typical solid-like behaviour with G'>G" (Fig. 4B). As the temperature is decreased, both moduli increased gradually until the temperature reached $10{ }^{\circ} \mathrm{C}$. At this temperature, the maximum of storage modulus is observed. The tertiary structure of cellulosic microfibrils, stabilized by numerous intermolecular $\mathrm{H}$-bonds and van der Waals forces, produces three-dimensional fibrous crystalline bundles (Milani \& Maleki, 2012). Vaikousi, Biliaderis, and Izydorczyk (2004) reported that the thermal profiles revealed changes in the network strength and/or changes in structural order (conformation) of the sequence segments involved in the bonding zones at high temperature.

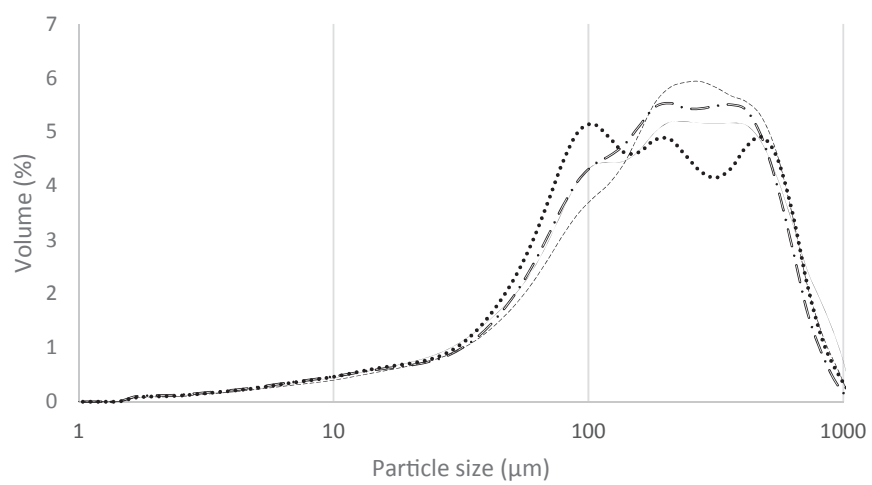

Fig. 6. Particle size distributions of pomegranate peels' suspensions $\left(\mathrm{S}_{\mathrm{F}}\right)$ after heating at $80^{\circ} \mathrm{C}-1 \mathrm{~h}$. Acide: $(--)$, Gabsi: (—), Nebli: ( $(\ldots)$, Tounsi $(-\cdot-\cdot)$.
3.1.3.2. Effect of calcium on fibrous material gelation. Fig. 4A shows the effect of calcium on the viscoelastic properties of the fibrous material gel (To). It is clearly seen that the $G^{\prime}$ and $G^{\prime \prime}$ values obtained for the two fibrous material gels To3 (in presence of calcium) and To3' (in absence of calcium) were superimposed. This indicates that the presence of calcium hadn't an effect on the viscoelastic properties of the fibrous material To network. It appears that the fibrous material sample To contains a too low amount of pectin requiring calcium for gelification.

\subsection{Microstructure of fibrous material gels}

Fibrous material gels (To1 and To6) prepared from Tounsi ecotype were visualised by light microscopy (Fig. 5). Fig. 5B shows the impact of mechanical treatment on the structure of fibrous material gel (To6). The micrographs show that the fibrous material gel To6 clearly appeared to form a denser network than that of the untreated sample To1. Thus, the mechanical treatment of fibrous material suspensions increases the particles hindrance, which explain the reinforcement of gel strength of To6.

\subsection{Particle size distribution}

Table 4 shows the peak particle size of pomegranate peel and fibrous material powders. Comparing the peaks of dry and $\mathrm{S}_{0}$ samples, it can be noticed that all samples exhibited an increase in

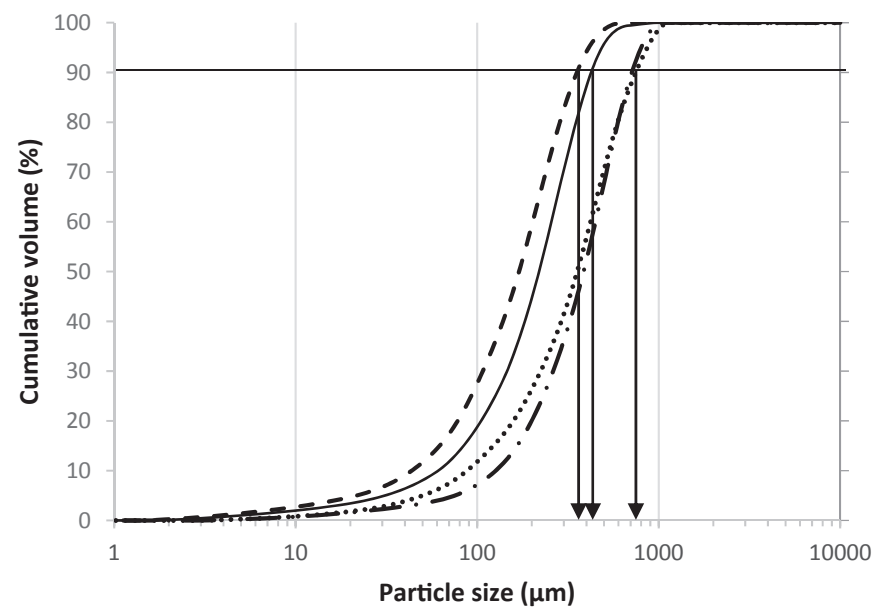

Fig. 7. Determination of $d(0.9)$ of Tounsi fibrous material suspensions from cumulated volume distribution curve. $\mathrm{S}_{0}:(-\cdot-), \mathrm{S}_{\mathrm{F}}:(\cdots \cdots), \mathrm{S}_{3}:(-), \mathrm{S}_{6}(---)$. 
particle size after hydration for $24 \mathrm{~h}$. This increase is related to the swelling capacity of particles which depend on their water-binding sites, polar groups and surface area. A single modal distribution was obtained for all varieties after hydration $\left(\mathrm{S}_{0}\right)$ with peak values in the range of $416-478 \mu \mathrm{m}$ and $478-549 \mu \mathrm{m}$ for peel and fibrous material samples, respectively. After heating at $82^{\circ} \mathrm{C}-1 \mathrm{~h}\left(\mathrm{~S}_{\mathrm{F}}\right)$, trimodal distributions with peak values in the range of $104-138 \mu \mathrm{m}$, 208-275 $\mu \mathrm{m}$ and 363-478 $\mu \mathrm{m}$ were obtained for peel samples (Table 4 and Fig. 6).

It is worth noting that temperature was an important factor that affected the particle size in all modes. As a matter of fact, by heating samples at $82{ }^{\circ} \mathrm{C}$ for $1 \mathrm{~h}$, in addition to the peak values of the bigger particles (corresponding to the third mode) two other modes with lower peak particle size appeared for all ecotypes. Probably the smaller particles consisted of individual cells from parenchyma tissue, while larger particles consisted of aggregates of cells (Espinosa et al., 2011).

For the fibrous material samples, Fig. 7 shows that suspensions mechanically dispersed $\left(S_{3}\right)$ had lower particle size than untreated ones $\left(\mathrm{S}_{0}\right)$. Indeed, a noticeable decrease of fibrous material's particle size was observed after mechanical stirring until 3 min with a decrease of $d(0.9)$ from 724 to $416 \mu \mathrm{m}$.

\section{Conclusions}

The rheological study of pomegranate peel suspensions provides a much better understanding of fibrous material and pectin contributions to the mechanical properties of peel gels at acidic $\mathrm{pH}(\mathrm{pH} 3)$. All peel samples show a rapid gel formation with $\mathrm{G}^{\prime}>\mathrm{G}^{\prime \prime}$ from the beginning of the measurement at high temperatures, which reveals a typically gel-like structure as a result of a synergism between fibrous material and pectins. The comparison between the four ecotypes studied shows that in the presence of fibrous material, an increase in peel gel strength is influenced by pectin characteristics (decreasing DM, decreasing neutral sugar content or increasing GalA content). During cooling from $90^{\circ} \mathrm{C}$ to $10{ }^{\circ} \mathrm{C}, \mathrm{G}^{\prime}$ increased with lower $\operatorname{tg} \delta\left(\mathrm{G}^{\prime \prime} / \mathrm{G}^{\prime}\right)$, reflecting stronger and more structured gels. Indeed, during cooling, the influence of hydrogen bonds should increase, supported by inter-chain interdimer associations, reflecting that more structured gels are build. The rheological properties of pectin and fibrous material gels, individually investigated, show that the peel gel properties seemed to be mostly governed by fibrous material. It was found also that the mechanical treatment of fibrous material suspensions had a significant effect on fibrous material gel strength improvement which was found to be related to the decrease of fibrous material's particle size (under 3 min of treatment) and to the heat induced by mechanical treatment noticed after 3 min. Hence the interest of thermo mechanical treatment of suspensions containing fibrous material for leading possibly to new functional properties.

\section{Acknowledgements}

This work was financed by the Ministry of Higher Education and Scientific Research - Tunisia to Mouna Abid for an internship at UMR Ingénierie Procédés Aliments and UMR408.

\section{References}

Agoda-Tandjawa, G., Durand, S., Berot, S., Blassel, C., Gaillard, C., Garnier, C., et al. (2010). Rheological characterization of microfibrillated cellulose suspensions after freezing. Carbohydrate Polymers, 80, 677-686.

Agoda-Tandjawa, G., Durand, S., Gaillard, C., Garnier, C., \& Doublier, J. L. (2012a). Properties of cellulose/pectins composites: Implication for structural and mechanical properties of cell wall. Carbohydrate Polymers, 90, 1081-1091.
Agoda-Tandjawa, G., Durand, S., Gaillard, C., Garnier, C., \& Doublier, J. L. (2012b). Rheological behaviour and microstructure of microfibrillated cellulose suspensions/low-methoxyl pectin mixed systems. Effect of calcium ions. Carbohydrate Polymers, 87, 1045-1057.

Axelos, M. A. V., \& Thibault, J. F. (1991). The chemistry of low-methoxyl pectin gelation. In R. H. Walter (Ed.), The chemistry and thechnology of pectin (pp. 109-118). New York: Academic Press.

Buchholt, H. C., Christensen, T. M. I. E., Fallesen, B., Ralet, M. C., \& Thibault, J. F (2004). Preparation and properties of enzymatically and chemically modified sugar beet pectins. Carbohydrate Polymers, 58, 149-161.

Cardoso, S., Coimbra, M., \& Silva, Lopes da (2003). Temperature dependence of the formation and melting of pectin-Ca2+ networks : A rheological study. Food Hydrocolloids, 17, 801-807.

Dhingra, D., Michael, M., Rajput, H., \& Patil, R. T. (2012). Dietary fibre in foods: A review. Journal of Food Science and Technology, 49, 255-266.

Dikeman, C. L., Murphy, M. R., \& Fahey, G. C., Jr. (2006). Dietary fibers affect viscosity of solutions and simulated human gastric and small intestinal digesta. Journal of Nutrition, 136, 913-919.

Espinosa, L., Toa, N., Symoneaux, R., Renard, C. M. G. C., Biau, N., \& Cuvelier, G. (2011). Effect of processing on rheological, structural and sensory properties of apple puree. Procedia Food Science, 1, 513-520.

Fraeye, I., Duvetter, T., Doungla, E., Loey, A. V., \& Hendrickx, M. (2010). Fine-tuning the properties of pectin-calcium gels by control of pectin fine structure, gel composition and environmental conditions. Trends in Food Science \& Technology, 21, 219-228.

Gelroth, J., \& Ranhotra, G. S. (2001). Food uses of fibre. In S. S. Cho, \& M. L. Dreher (Eds.), Handbook of dietary fibre (pp. 435-449). New York: Marcel Dekker.

Guillon, F., \& Champ, M. (2000). Structural and physical properties of dietary fibres, and consequences of processing on human physiology. Food Research International, 33, 233-245.

Hwang, J., \& Kokini, J. L. (1992). Contribution of the side branches to rheological properties of pectins. Carbohydrate Polymers, 19, 41-50.

Imeson, A. (2010). Food stabilisers, thickeners, and gelling agents. Chichester: WileyBlackwell (Chapter 10).

Kim, W. J., Rao, V. N. M., \& Smit, C. J. B. (1978). Effect of chemical composition on compressive mechanical properties of low ester pectin gels. Journal of Food Science, 43, 572-575.

Kunzek, H., Muller, S., Vetter, S., \& Godeck, R. (2002). The significance of physicochemical properties of plant cell wall materials for the development of innovative food products. European Food Research and Technology, 214, 361-376.

Lowys, M. P., Desbrie Áres, J., \& Rinaudo, M. (2001). Rheological characterization of cellulosic microfibril suspensions. Role of polymeric additives. Food Hydrocolloids, 15, 25-32.

Mditshwa, A., Fawole, O. A., Al-Said, F., Al-Yahyai, R., \& Opara, U. L. (2013). Phytochemical content, antioxidant capacity and physicochemical properties of pomegranate grown in different microclimates in South Africa. South African Journal of Plant and Soil, 30, 81-90.

Milani, J., \& Maleki, G. (2012). Hydrocolloids in food industry. In B. Valdez (Ed.), Food industrial processes - Methods and equipment (ISBN 978-953-307-905-9). Croatia: InTech publication.

Pereira, P. H., Oliveira, T.Í., Rosa, M. F., Cavalcante, F. L., Moates, G. K., Wellner, N. et al. (2016). Pectin extraction from pomegranate peels with citric acid. International Journal of Biological Macromolecules, 88, 373-379.

Poutanen, K., Suirti, T., Aura, A. M., Luikkonen, K., \& Autio, K. (1998). Influence of processing on the cereal dietary fibre complex: What do we know? In F. Guillon, et al. (Eds.), Proceedings of the PROFIBRE Symposium, Functional properties of non-digestible carbohydrates (pp. 66-70). Nantes: Imprimeric Parentheses.

Raghavendra, S. N., Ramachandra Swamy, S. R., Rastogi, N. K., Raghavarao, K. S. M. S. Kumar, S., et al. (2006). Grinding characteristics and hydration properties of coconut residue: A source of dietary fibre. Journal of Food Engineering, 72, $281-286$.

Rinaudo, M. (1996). Physicochemical properties of pectins in solution and gel states. In J. Visser, \& A. G. J. Voragen (Eds.), Pectins and pectinases (pp. 21-34). New York: Elsevier.

Smidsrod, O., \& Haug, A. (1971). Estimation of relative stiffness of the molecular chain in polyelectrolytes from measurements of viscosity at different ionic strengths. Biopolymers, 10, 1213-1227.

Speiser, R., Copley, M. J., \& Nutting, G. C. (1947). Effect of molecular dissolution and charge distribution on the gelation of pectin. Journal of Physical Chemistry, 51, 117-133.

Srivastava, P., \& Malviya, R. (2011). Sources of pectin, extraction and its applications in pharmaceutical industry - an overview. Indian Journal of Natural Products and Resources, 2, 10-18.

Tatsumi, D., Kourogi, H., Chen, B., \& Matsumoto, T. (2008). Effect of natural additives on the rheological properties of cellulose fiber disperse systems. Colloids and Surfaces A. Physicochemical and Engineering Aspects, 316, 151-158.

Thakur, B. R., Singh, R. K., \& Handa, A. K. (1997). Chemistry and uses of pectin- a review. Critical Reviews in Food Science and Nutrition, 37, 47-73.

Thibault, J. F., Renard, C. M. G. C., Axelos, M. A. V., Roger, P., \& Crépeau, M. J. (1993). Studies on the length of homogalacturonic regions in pectins by acid hydrolysis Carbohydrate Research, 238, 271-286.

Vaikousi, H., Biliaderis, C. G., \& Izydorczyk, M. S. (2004). Solution flow behavior and gelling properties of water-soluble barley $(1 \rightarrow 3,1 \rightarrow 4)$ - $\beta$-glucans varying in molecular size. Journal of Cereal Science, 39, 119-137. 
Version définitive du manuscrit publiée dans / Final version of the manuscript published in :

Food Hydrocolloids (2017), Vol. 215, p. 174-181, DOI: 10.1016/j.foodhyd.2016.08.008

Journal homepage : www.elsevier.com/locatelfoodhyd

Vincken, J. P., Schols, H. A., Oomen, R., McCann, M. C., Ulvskov, P., Voragen, A. G. J., et al. (2003). If homogalacturonan were a side chain of rhamnogalacturonan I Implications for cell wall architecture. Plant Physiology, 132, 1781-1789.

Voragen, A. G. J., Pilnik, W., Thibault, J. F., Axelos, M. A. V., \& Renard, C. M. G. C.
(1995). Pectins. In A. M. Sephen (Ed.), Food polysaccharides and their applications (pp. 287-339). NewYork: Marcel Dekker Inc.

Zykwinska, A. W., Ralet, M. C. J., Garnier, C. D., \& Thibault, J. F. J. (2005). Evidence for in vitro binding of pectin side chains to cellulose. Plant Physiology, 139, 397-407. 